\title{
Trust and Loyalty Level of Online Transportation Users
}

\author{
Herman Soegoto \\ Magister Manajemen \\ Universitas Komputer Indonesia \\ Bandung, Indonesia \\ herman.soegoto@email.unikom.ac.id
}

\begin{abstract}
Main objectives of this research are to find out the trust level among Bandung citizens and the impact towards online based transportation users loyalty. This research is used combination of descriptives and verificative analysis, and the data came from 400 respondents in 30 districts, which located in Bandung city. Data is collected by utilizing the questionnaire that distributed in proportional systematic random sampling. Moreover, this research used a simple regression analysis performed with the SPSS 17 to test the hypotheses. The result of this research concluded that the trust and loyalty level is high enough, and there is a positive influence of trust to the loyalty level of online based transportation customer in Bandung.
\end{abstract}

Keywords—online transportation, trust, loyalty, bandung

\section{INTRODUCTION}

Recently with the rapid development in the information technology sector, the internet connection that can reach allregion in a country has given an enormous transformation in citizen's life. The citizens got used to communicating by using the internet connection. The internet connection did not only used for social activity to communicate over a long distance but also for business. The used of smartphone that is connected to the internet connection make citizens easier to communicate and to perform buying and selling transaction online. Mobile communication has made an impact towards interaction between people while conducting business either locally or internationally [1].

One of the business models that grow recently is online transportation. This business model enables citizens to order the transportation using their smartphone with high ease and flexibility. Furthermore, the price of this online transportation is cheaper than the offline taxi or ojek. Looking to the future, smartphone applications and more specifically multimodal aggregators, may offer the potential for transportation planners and policymakers to enhance their understanding of multimodal travel behavior, share data, enhance collaboration, and identify opportunities for publicprivate partnerships [2].

In 2015, there has been a massive change in the transportation service sector. Previously consumers have to wait for a taxi on the edge of the road or they have to order it through the taxi operator office, or even the consumers have to bargain for the price with the taxi driver, and suddenly everything changes since the online transportation service enter the market. In twelve months, Go-jek has developed from the new mobile application to a huge service that afterwards emerges competitor from GrabTaxi with the GrabBike service. The competition becomes fiercer due to the entry of an American online transportation service to Indonesia in 2014 that called Uber. Entering 2016, the competition between those three start-ups keeps increasing. GrabTaxi change their name to Grab and try to compete with Go-jek on food delivery business by creating GrabFood service. When Go-jek launched Go-pay, Grab respectively launched a similar feature that called GrabPay Credits. In order to compete with GrabBike and Go-jek, Uber generated UberMotor. After Uber launched UberMotor Go-jek create Go-car one week later.

In the beginning, a quite huge contrary came from conventional taxi firms and ojek drivers. Demonstration against online transportation service occurred at Jakarta, Bandung, Surabaya and other big cities in Indonesia. Despite the contrary and demonstration, the existence of online transportation can be accepted by most of the citizens and the acceptance keeps expanding recently.

The total of online transportation users in December 2017 reach approximately 15.73 million users, and market share from Go-Jek, Grab, and Uber is $29.6 \%$ of all mobile application users [3].

Apparently, the consumer trust level is quite high, and it showed when consumers decide to change their preferences from conventional transportation to online transportation based. When consumers are considering a service to use, the main influential factor is whether the consumers trust the service or not, and this method also applied to online transportation service. Trust can be defined as confidence that one party has on another because of honesty and reliability of the other partner [4]. Griffin mentions that the thing in the consumer mind when he/she wanted to create a relationship is whether those firms could be trusted [5]. When the costumer trust the company they will tend to reuse or recomended the product to others. Zeithaml dan Bitner state that users loyalty characteristics that based on behavior and attitude dimension are recommending positive things of the firm to another person, carry out more business with firms in the future, considering firms as their first choice in the future [6].

So far, there is no reasearch yet is conducted to measure the trust and loyalty level for the online based transportation user in Indonesia. This research aims: to find out Bandung citizens level of trust towards online transportation method, to find out Bandung citizens loyalty level towards online transportation method, and to find out the effect of trust level towards citizen's loyalty that is using online transportation. 


\section{METHOD}

This research is aimed at investigating the level of costumer trust and loyalty, and also the influence of trust on loyalty. The units of analysis for this research were 400 respondents from 30 region in Bandung city. Samples were taken on May-July 2017. Questionere been drawn by means of proportional systematic simple random sampling. This research used a Simple Regression analysis peformed with the help of SPSS 17 to test the hypotheses.

\section{RESULTS AND DISCUSSIONS}

\section{A. Respondent Data}

The survey is conducted to Bandung citizens who use online transportation service. Samples were taken proportionally based on total citizens of each district with distributionas table 1 .

TABLE I. POPULATION AND Distribution SAMPLE

\begin{tabular}{|c|c|c|c|}
\hline No & District & Population Number & n (sample size) \\
\hline 1 & Bandung Kulon & 143,313 & 23 \\
\hline 2 & Babakan Ciparay & 148,025 & 23 \\
\hline 3 & Bojongloa Kaler & 121,165 & 19 \\
\hline 4 & Bojongloa Kidul & 86,363 & 14 \\
\hline 5 & Astanaanyar & 68,991 & 11 \\
\hline 6 & Regol & 81,987 & 13 \\
\hline 7 & Lengkong & 71,637 & 11 \\
\hline 8 & Bandung Kidul & 59,331 & 10 \\
\hline 9 & Buah Batu & 95,356 & 15 \\
\hline 10 & Rancasari & 75,469 & 12 \\
\hline 11 & Gedebage & 35,910 & 6 \\
\hline 12 & Cibiru & 70,370 & 11 \\
\hline 13 & Panyileukan & 39,339 & 6 \\
\hline 14 & Ujungberung & 75,477 & 12 \\
\hline 15 & Cinambo & 24,766 & 4 \\
\hline 16 & Arcamanik & 68,293 & 11 \\
\hline 17 & Antapani & 74,557 & 12 \\
\hline 18 & Mandalajati & 63,147 & 10 \\
\hline 19 & Kiaracondong & 132,135 & 21 \\
\hline 20 & Batununggal & 121,076 & 20 \\
\hline 21 & Sumur Bandung & 35,903 & 6 \\
\hline 22 & Andir & 97,693 & 16 \\
\hline 23 & Cicendo & 99,898 & 16 \\
\hline 24 & Bandung Wetan & 30,939 & 5 \\
\hline 25 & Cibeunying Kidul & 108,193 & 17 \\
\hline 26 & Cibeunying Kaler & 71,184 & 11 \\
\hline 27 & Coblong & 132,002 & 21 \\
\hline 28 & Sukajadi & 108,512 & 17 \\
\hline 29 & Sukasari & 82,012 & 13 \\
\hline 30 & Cidadap & 58,426 & 9 \\
\hline
\end{tabular}

\section{B. Trust Level}

Trust is defined as a belief of one party that other party will be fulfilling their needs and wants. As far as services are concerned, trust is the confidence that customers have on the provider of services to fulfill their needs [7].

Various situation and indications of trust that stated by Mitchell in Egan, as follows: Probity (focus on honesty and integrity); Equity (related to fair-mindedness, benevolence, caring, and sincerity); Reliability (related to trustworthy, accuracy, and consistency from a product or service which are expected to be related with the guarantee that issued by the firm in several aspects) [9]. Consumers trust level criteria is measure by referring to the table 2

TABLE II. REPONDENT PERCEPTION OF PERCENTAGE SCORE CRITERIA TOWARDS IDEAL SCORE

\begin{tabular}{|c|c|c|}
\hline No & \% Total Score & Criteria \\
\hline 1 & $20.00-36.00$ & Very Low \\
\hline 2 & $36.01-52.00$ & Low \\
\hline 3 & $52.01-68.00$ & medium \\
\hline 4 & $68.01-84.00$ & High \\
\hline 5 & $84.01-100$ & Very High \\
\hline
\end{tabular}

Based on the data that processed from 400 respondents in Bandung City is known that probity that was measured by the trust level of online transportation utilisation/use is $70 \%$, online transportation drivers integrity level is $69 \%$, reputation level of online transportation firms is $71 \%$, and online transportation consumers trust level compare to the conventional transportation in Bandung is $73 \%$. Therefore, it could be concluded that the average probity is in the good category with the score of $71 \%$. However, apparently from the integrity side of online transportation driver, the score is almost approach medium category.

Equity or commitment level or justice that measured by the level of online transportation driver's commitment to the consumers and guaranteed level of fair treatment from online transportation are high which obtain $73 \%$ and $70 \%$ for the score.

Reliability or the service consistency that measured by consistency level in equal good service between different online transportation drivers is $69 \%$ and the giving service on time is $70 \%$. Even though those scores still categorize as good but these scores approach medium category.

Based on Fig.1 from the three categories of trust level, the online transportation firms still need to develop the trust level of online transportation users. The reason is in the sector of service trust level which categorises as good might not enough to make consumer become loyal due to the possibility that consumers may shift their preferences to other firms that have higher or extremely high trust level. 


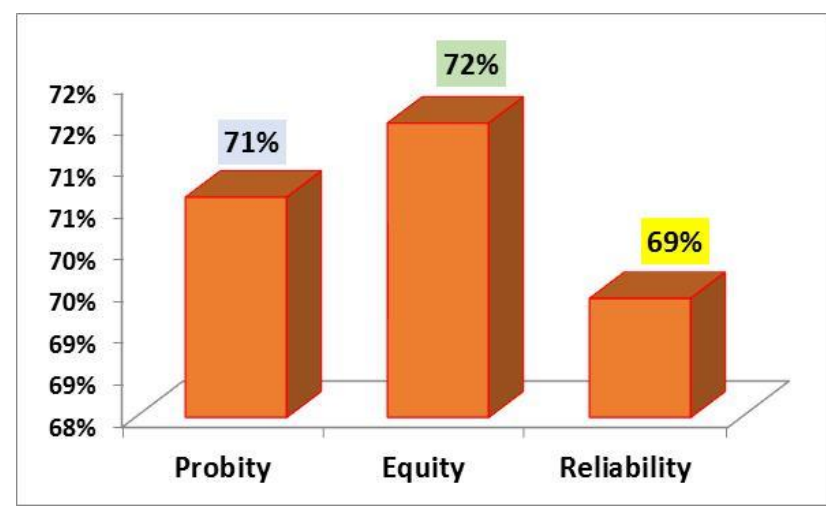

Fig. 1 - Trust Level

\section{Loyalty Level}

Customer loyalty is defined as promise of buyers to purchase particular products, services and brands of an organization over a consistent period of time, irrespective of competitor's new products and innovations and these customers are not compelled to switching [10]. Griffin indicate loyal users characteristics based on: makes regular repeat purchases, purchases across product and service lines, refers other, demonstrates immunity to the full of the competition [5]. Loyal customers are valuable resources for organizations because it is easier to sell to an old customer than a new one [11].

Loyalty level of online transportation users could be measured by four loyal consumers criteria according to the theory that stated by Griffin [5]. Based on the survey result, the desire of online transportation users to continue using online transportation is $74 \%$, the inclination to recommend online transportation to other people is $71 \%$, the desire to utilise online transportation rather than conventional transportation that available is $69 \%$, the rejection level to use convention transportation is $61 \%$.

According to the data as shown on Fig.2, consumers are likely to recommend online transportation to other people, but they still wanted sometime to use conventional/nononline transportation that already exists before based on its importance.

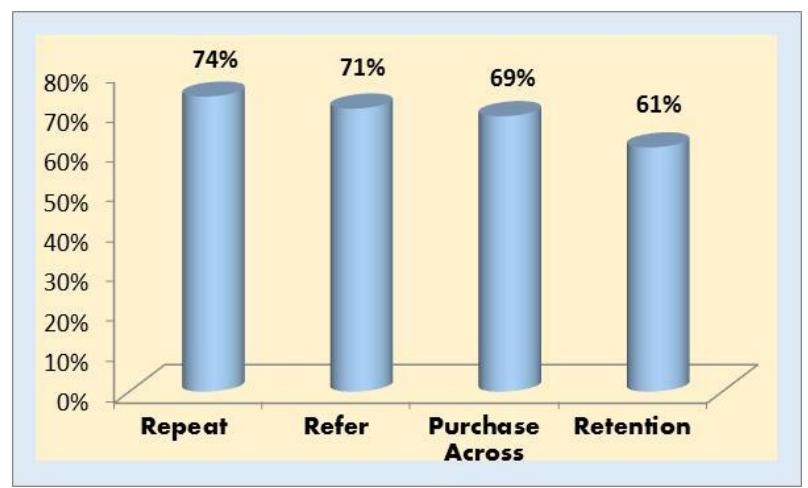

Fig. 2. Costumer Loyalty Level

D. Transportasi Online Relationship between the trust level perception and loyalty level of online transportation users
Analysis to view how much changes that occurred in loyalty level due to the influence of online transportation users trust level is illustrated as follows:

TABLE III. MODEL SUMMARY BETWEEN TRUST AND LOYALTY

\begin{tabular}{|l|r|r|r|r|r|}
\hline Model & \multicolumn{1}{|r|}{$\begin{array}{c}\mathbf{R} \\
\text { Square }\end{array}$} & $\begin{array}{c}\text { Adjusted R } \\
\text { Square }\end{array}$ & $\begin{array}{l}\text { Std. Error of } \\
\text { the Estimate }\end{array}$ & $\begin{array}{l}\text { Durbin- } \\
\text { Watson }\end{array}$ \\
\hline 1 & $.570^{\mathrm{a}}$ & .325 & .323 & .57920 & 1.886 \\
\hline
\end{tabular}

According to figure $3,32.5 \%$ information which contained in loyalty level could be explained by the shift that occurred in consumers trust level who use online transportation, while $67.5 \%$ is influenced by other variables that were not discussed in this proceeding.

TABLE IV. COEFFICIENT CORELLATION BETWEEN TRUST AND LOYALTY

\begin{tabular}{|c|c|c|c|c|c|c|}
\hline \multicolumn{2}{|c|}{ Model } & $\begin{array}{r}\text { Unstand } \\
\text { Coeffi } \\
B\end{array}$ & $\begin{array}{l}\text { dardized } \\
\text { icients } \\
\text { Std. Error }\end{array}$ & \multirow[t]{2}{*}{$\begin{array}{c}\text { Standardized } \\
\text { Coefficients } \\
\text { Beta }\end{array}$} & \multirow{2}{*}{$\begin{array}{l}\mathbf{t} \\
5.852\end{array}$} & \multirow{2}{*}{$\begin{array}{r}\text { Sig. } \\
.000\end{array}$} \\
\hline 1 & (Constant) & 1.056 & .181 & & & \\
\hline & $\mathrm{T}$ & .692 & .050 & .570 & 13.842 & .000 \\
\hline
\end{tabular}

a. Dependent Variable: L

Based on the data in figure 4 , the value of measured $t$ is 13.842 bigger than the value of table $t$ with 1.96 , which means that statistically trust level positively affects the loyalty level of online transportation users.

The relationship between loyalty and trust level of online transportation users can be illustrated as follows: Loyalty = $1.056+0.692$ Trust

The result of these researches is similar to the opinion from Koupai et.al. who stated that satisfaction variable is mediator in trust and has a positive and significant influence on establishment of loyalty [11]. Perceived value relates positively to loyalty, and that trust mediates that relationship [12]. There is positive relationship between trust and customer loyalty [13].

Customer trust intervenes as a mediating variable that enhances the impact of corporate identity, corporate image and the reputation of the firm on customer loyalty [6]. 


\section{CONCLUSION}

Consumer's trust and loyalty level of online transportation users might be concluded as follows: Bandung citizens trust level towards the online transportation method in average is good, Bandung citizens' loyalty level to repeatedly use and recommend online transportation to other people is categorised as good, but the retention level and probability to choose other transportation method is quite low. User's trust level influence the consumer loyalty of online transportation users.

\section{REFERENCES}

[1] A. Rahim, S. Z. Safin, L.K. Kheng, N. Abas, and S. M. Ali, "Factors influencing purchasing intention of smartphone among university students," Fifth International Conference on Marketing and Retailing, Procedia Economic and Finance 37, 2016, pp.245-253.

[2] S. Shaheen, E. Martin, A. Cohen, A. Musunuri, and A. Bhattacharyya, "Mobile Apps and Transportation: A review of smartphone Apps and a study of user response to multimodal traveler information", Final Report, California Department of Transportation, 2016.

[3] https://www.idntimes.com/business/economy/putrian a-cahya persaingan -tiga-transportasi-online-terbesar/full

[4] R. M. Morgan, \& S. Hunt, "Relationship-based competitive advantage: the role of relationship marketing in marketing strategy". Journal of Business, 1999, pp 281- 290.

[5] J. Griffin, "Customer Loyalty How To Earn it, How To Keep It," Kentucky: Mc.Graw Hill, 2002, pp1-78.

[6] Zeithaml, V., Bitner M.J. \& Gremler, D. (2006). Service Marketing, Singapore: McGraw-Hill International Edition, 2006, p201.

[7] R.Gul, "The Relationship between Reputation, Customer Satisfaction, Trust, and Loyalty." Journal of Public Administration and Governance ISSN 2161-7104, 2014, Vol. 4, No. 3.

[8] S. Shaheen, E. Martin, A. Cohen, A. Musunuri, and A. Bhattacharyya, " Mobile Apps and Transportation: A review of smartphone Apps and a study of user response to multimodal traveler information", Final Report, California Department of Transportation, 2016.

[9] J. Egan, "Relationship Marketing: Exploring Relational Strategies in Marketing," England: Prentice Hall, 2004, pp56-149.

[10] R.L. Oliver, "Relationship of satisfaction and Loyalty," Journal of Marketing, 1999 Vol.63. pp335-399.

[11] M. R. Koupai, Z. Alipourdarvish, and S. Sardar, "Effects of trust and Perceived value on customer loyalty by mediating role of customer satisfaction and mediating role of customer habit (case study: Agricultural internet bank customers in Tehran". Journal of Advanced Social Humanities and Management, 2015, 2(1):102-112.

[12] H. Karjaluoto, C. Jayawardhena, M. Leppäniemi, and M. Pihlström, "How value and trust influence loyalty in wireless telecommunications industry. Telecommunications Policy, 2012, 36 (8), 636-649. doi:10.1016/j.telpol.

[13] F.A. Rasheed, and M.F. Abadi, "Impact of service quality, trust and perceived value on customer loyalty in Malaysia services industries," International Conference on Accounting Studies, Kuala Lumpur, Malaysia. Procedia - Social and Behavioral Sciences, 2014, 164: 298 -304 . 